Article

\title{
Ranking of Risks for Existing and New Building Works
}

\author{
Rita Yi Man $\mathrm{Li}^{1, * \mathbb{C}}$, Kwong Wing Chau ${ }^{2} \mathbb{D}$ and Frankie Fanjie Zeng ${ }^{3}$ \\ 1 Department of Economics and Finance/Sustainable Real Estate Research Center/HKSYU Real Estate and \\ Economics Research Lab/Centre of Interdisciplinary Research in Evidence-based Practice, \\ Hong Kong Shue Yan University, Hong Kong, China \\ 2 Ronald Coase Centre for Property Rights Research, The University of Hong Kong, Pokfulam Road, \\ Hong Kong, China; hrrbckw@hku.hk \\ 3 Faculty of Social Science, Chinese University of Hong Kong, Hong Kong, China; \\ frankiezeng@link.cuhk.edu.hk \\ * Correspondence: ymli@hksyu.edu or ritarec@hotmail.com
}

Received: 8 April 2019; Accepted: 14 May 2019; Published: 20 May 2019

\begin{abstract}
Site safety is one critical factor affecting the sustainability of skyscrapers and decoration, repair, and maintenance projects. Many newly-built skyscrapers exceed 50 storeys in Hong Kong and decoration, repair, and maintenance projects are widely performed to extend the lifespans of buildings. Although many cities do not contain skyscrapers at present, this will change in the future. Likewise, more decoration, repair, and maintenance projects will emerge. Thus, the present research, which compares the safety risks among the new and DSR projects, provides insights for builders, policymakers, and safety personnel. Moreover, research studies which rank and compare decoration, repair, and maintenance projects and new skyscraper constructions are scarce. The use of the evidence-based practice approach, which aims to narrow the gap between practice and academia in construction safety research, is the first of its kind. In this paper, we firstly provide a systematic literature review from 1999 to 2019 regarding construction safety, and then study the industry's perspectives by analysing the construction practitioners' interview results, court cases, and analytic hierarchy process survey results to compare them with the literature. It is found that the generation gap and prolonged working hours lead to accidents-a phenomenon which is unique in Hong Kong and absent from the literature. It also reveals that most accidents happen on new building sites due to tower crane failure, while those on DSR projects are linked with the circular saw. Although many of the contractors involved in new buildings are wealthier than DSR contractors, it is surprising to learn that lack of funding for safety is the most important factor linked to safety risks on the sites.
\end{abstract}

Keywords: evidence-based practice; construction safety; AHP; sustainable risk ranking

\section{Introduction}

Wu et al. [1] suggested that construction safety affects project sustainability and portfolio success. Nawaz conceded that ignoring safety results in adverse consequences for sustainability [2]. Thus, safety is one of the items with a high priority in engineering projects [3], including new building and decoration, repair, and maintenance (DSR) projects. According to the Hong Kong Census and Statistics Department, the total population in Hong Kong will reach a peak of 8.22 million people in 2043 [4]. However, the availability of vacant land for building construction is limited. Thus, more skyscrapers are being constructed following a "build up, not out" approach [5]. Moreover, the policy regarding the extra gross floor area offers developers bonuses and exemptions for green feature provisions, which have become powerful motivations for developers to increase both the number of floors and 
the mass of buildings [6]; as a result, Hong Kong has the largest number of tall buildings above 150 metres worldwide.

Nevertheless, the methods used to construct a skyscraper are different from those used for 20-30-storey buildings. Indeed, Hong Kong provides a special case to study construction safety issues, because skyscrapers constitute the trend in densely populated cities, and the results can readily be generalised to other urban areas. In addition, Hong Kong boasts the longest working hours amongst 71 cities [7], and such long workdays may be linked to a high accident rate. Moreover, similar to many other developed cities, Hong Kong is facing the problem of an ageing population [8]; different generations have their characteristics [9], and communication across generations poses many challenges. All these phenomena make Hong Kong a unique place, and one in which the construction safety issue is worth studying.

Meanwhile, large building volumes imply an enormous demand for refurbishment and repair. Small-scale DSR projects are undertaken daily to extend the lifespans of obsolete buildings, meet the occupants' demands and maintain environmental sustainability [10]. Thus, the number of construction workers has increased in recent years [4]. Additionally, accidents may occur during new building projects due to the complexity of work; indeed, work-related injuries on DSR projects are not uncommon.

In comparison with new building construction projects, DSR projects are less expensive [11]. Moreover, the increment in the market value substantially outweighs the cost, although the scale of work in a DSR project is usually smaller than that of new building construction, and the level of subcontracting is typically lower with fewer job requirements. Nevertheless, the regulations for DSR and buildings are the same in many cities. In this regard, we aim to provide a comparison of the factors that lead to construction-related accidents in high-rise building and DSR projects.

\section{Materials and Methods}

Originating from clinical research, evidence-based practice (EBP) is both a goal and a method that suggests decisions should be made according to the up-to-date, valid, and appropriate evidence. Defined as a combination of clinical experience and recent credible research evidence, the evidence is obtained from systematic reviews or well-designed clinical trials [12]. The root metaphor of contemporary, idiographic evidence-based practice is the three circles, also known as the three-legged stool: (a) the best available research evidence; (b) clinical expertise; and (c) patient values, preferences, characteristics, and circumstances [13]. Besides this, EBP typically involves four major activities: ask, acquire, appraise, and apply the research materials [14]. Among all the available evidence, a systematic review of the previous literature is considered the highest form of evidence, as it is a systematic search which identifies and summarises all of the available evidence to answer a research question [15].

Since its introduction in the 1990s, the principles of EBP have been revised and extended to many disciplines, such as public policy [16,17], youth [18] and social work [19]. To the best of our knowledge, no EBP research has been performed on construction. We attempt to utilise the evidence-based practice research approach under a modified three-legged tool, comprising: (a) systematic review of the available research evidence from peer-reviewed journal articles; (b) evidence obtained from court and safety officers' expertise; and (c) construction practitioners' perceptions. The purpose of this is to narrow the gap between research and practical applications in various sources of evidence [20].

In this research, a systematic review was carried out to analyse the distal and immediate causes of construction accidents which have happened in the past. Because judges consider the evidence of all stakeholders involved in a case, court cases represent one of the most objective sources for identifying the causes of construction accidents [21]. Thus, by searching for the phrase "construction accident" in Westlaw and HKLII, it was possible to collect both building and DSR court cases throughout Hong Kong from 1986 to mid-2016.

As most construction accidents do not require legal recourse, in-depth and face-to-face or telephone qualitative interviews lasting between 30 and 120 minutes were conducted with 44 construction experts in the construction industry, including experienced safety officers, CEOs of the firms and 
professionals; the goal of this was to determine the five most predominant factors that lead to accidents. Semi-structured interviews allowed for an increase in flexibility while addressing the stakeholders' experiences, thereby diminishing any retrospective biases [22].

The abovementioned court cases and interview results laid a solid foundation for producing the questions in the analytic hierarchy process (AHP) questionnaires, which were administered to construction personnel to assess their reactions and perspectives.

Content analysis was adopted to study court cases and interviews in Hong Kong. This type of analysis enables similar categories of information to be grouped to create systematic and objective analysis criteria [23]. With regard to the nature of the questionnaires, Kaya and Kahraman [24] put forth the belief that the AHP, which was developed by Saaty, represents the most accurate approach for quantifying the weights of criteria. In the AHP, individual experts' experiences are utilised to estimate the relative magnitudes of factors through pair-wise comparisons [25]. Each of the respondents has to compare the relative importance of the two items. Abu Taha and Daim [26] suggested that the AHP achieves a consistent judgement. This computational algorithm allows for the hierarchical structurisation of a decision problem [27]. Furthermore, the AHP approach can identify the relative importance of factors attributed to accidents in both new building construction and DSR projects [28] via the following steps:

1. Define the main criteria and sub-criteria of the target at the top level.

2. Sort the complex problem into a multi-level hierarchical structure.

3. Construct pair-wise matrices to compute the priorities [29,30]:

$$
\mathrm{AW}=\lambda_{\max } W, w=(w 1, w 2, w 3, \ldots w n)^{T}
$$

where $\mathrm{A}$ is the priority matrix of size $\mathrm{n}$ for $\mathrm{n}$ criteria, $\mathrm{w}$ is the Eigenvector of size $\mathrm{n} 1$, which is the weight. $\lambda_{\max }$ is the maximum Eigenvalue [31].

4. Compute the option scores matrix [30]: Assume there exists an mxn real matrix P. Each entry $\mathrm{P}_{i j}$ of $P$ represents the score of an $i$ th option with respect to the $j$ th criterion. A pairwise comparison matrix $C(j)$ is firstly built for each of the criteria $\mathrm{m}$ where $j=1, \ldots, \mathrm{m}$ or each of the $\mathrm{m}$ criteria. The matrix $C(j)$ is an mxn real matrix where $\mathrm{n}$ is the number of alternatives. Each element $c_{i h}^{j}$ of the matrix $C^{j}$ represents an evaluation of the ith alternative as compared to the hth alternative with respect to the jth criterion. Besides this, the same process as that described for the pairwise comparison matrix $\mathrm{A}$ is applied to each matrix $C^{j}$, and alternative vectors $p^{j}(j=1, \ldots, \mathrm{m})$ are obtained. The vector $p^{j}$ contains the evaluated options scores with respect to the jth criterion and the score matrix $\mathrm{P}$ is constructed as $\mathrm{P}=\left[p^{l} \ldots p^{m}\right]$. Finally, the score $\mathrm{v}$ is obtained by multiplying the score of matrix $\mathrm{P}$ by weight vector $\mathrm{v}=\mathrm{P} \cdot \mathrm{w}$ where the ith element of $\mathrm{v}_{\mathrm{i}}$ of $\mathrm{v}$ represents the ith alternative calculated by AHP.

5. Calculate the consistency index (CI) [31]:

$$
\mathrm{CI}=(\zeta \max -\mathrm{n}) /(\mathrm{n}-1)
$$

Perfectly consistent estimations scenario occurs when $C I=0$, small values of inconsistency can be accepted. The random index (RI) is adopted as the consistency index when the matrix entries are random and consistency ratio $=\mathrm{CI} / \mathrm{RI}$. If CI falls on an acceptable range when its value is less than 0.1 . 


\section{Results}

\subsection{Systematic Literature Review}

\subsubsection{Distal Cause}

Previous research has shown that several factors can lead to work-related accidents-e.g., as the company size increases, the incidence rate decreases due to the provision of better occupational health and safety programmes [32] —and thus various algorithms have been developed for safety engineering, such as the opposite degree algorithm [33] and neural network [34]. In addition, the limited enforcement of safety regulations can affect workers' safety conditions [35]. High accident rates can result from irregular employment, long commutes, and employer policies regarding health and safety [36].

\subsubsection{Proximal Cause}

Similarly, Chi et al. [37] attested that the major causes of accidents are attributed to falls. In the US, 8880 fatal work-related falls were recorded from 2003 to 2014, at an annual rate of 5.5 falls per million full-time equivalents, and this rate increased with age. Occupations with the highest rates included extraction/construction and repair/maintenance/installation [38]. Kaskutas et al. [39] identified that a lack of safety training with regard to falling from ladders and insufficient quality of training result in a lower level of hazard perception. A further contributing factor is the pressure to meet deadlines, which outranks safety considerations.

Chinniah [40] suggested that the causes of injuries incurred from being struck by moving machinery on the work site in Quebec are mainly due to the poor quality of the machinery used in design and operation endeavours. Aneziris et al. [41] identified that working near cranes, mechanical lifting devices, propelled vehicles, falling objects and manually-handled loads increase the risk of an accident. Similarly, Aneziris, Papazoglou, Mud, Damen, Bellamy, Manuel, and Oh [41] found that working near a mechanical lifting device carries the highest risk of an accident. Additionally, an analysis of 519 incidents in Bahrain, Kuwait, Qatar, the UAE and Saudi Arabia revealed that workers' skills and training correlate with being struck by falling objects [42]. The difference in the nature between new building and DSR projects leads to substantial differences in the causes of accidents; however, this difference has not been covered in the literature as per Table 1.

Table 1. Causes of construction accidents recorded in previous literature.

\begin{tabular}{cc}
\hline Construction Accidents Factors & Literature \\
\hline Distal Factors & Workers \\
\hline Aged worker & $\begin{array}{c}\text { Dumrak et al. [43]; Rameezdeen and Elmualim [44]; Socias-Morales, } \\
\text { Chaumont Menéndez and Marsh [38]; Chiang et al. [45] } \\
\text { Fatigue }\end{array}$ \\
Health & Evanoff, Rohlman, Strickland, Kelly and Dale [36] \\
Human error & Garrett and Teizer [48]; Zhi et.al. [49]; Li et al. [50] \\
Poor training & Chan et.al. [51]; Debrah and Ofori [52]; Kaskutas, Dale, Lipscomb \\
Pressure & and Evanoff [39]; Liu et.al. [53]; Zahoor et al. [54] \\
Insufficient safety & Harvey et al. [55] \\
knowledge/inexperienced & Atkinson et al. [56]; Mitropoulos et al. [57]; Le et al. [58]; Li [59]; \\
Migrant & Lingard et al. [60] \\
Poor safety attitude & Debrah and Ofori [52]; Hassan and Houdmont [61] \\
Social capital & Toole [62]; Teo et al. [63]; Yu et al. [64] \\
Workers' actions & Wu, Chong, Wang and Li [1] \\
Young & Winge et al. [66] \\
Construction task planning & Chi et al. [37]; Arquillos et al. [67] \\
Akhmad et al. [68]
\end{tabular}


Table 1. Cont.

\begin{tabular}{|c|c|}
\hline Construction Accidents Factors & Literature \\
\hline \multicolumn{2}{|l|}{ Distal Factors } \\
\hline \multicolumn{2}{|r|}{ Workers } \\
\hline Stress & Irumba [65] \\
\hline Design & $\begin{array}{c}\text { Gambatese and Hinze [69]; Behm [70]; Gambatese et al. [71]; } \\
\text { Arocena and Núñez [72]; Kongtip et al. [73]; Bong et al. [74,75]; } \\
\text { Malekitabar et al. [76] }\end{array}$ \\
\hline Dominant firm's share & Decker and Flynn [77] \\
\hline Near-miss management & Zhou et al. [78] \\
\hline Housekeeping & Toole [62]; Haslam et al [56], Hu [79]; Ahmad et al. [80] \\
\hline & Toole [62]; Haslam et al. [56]; Eliufoo [81]; Cheng and Wu [82]; \\
\hline Protective equipment & $\begin{array}{l}\text { Gibb et al. [83]; Ahmad, Iraj, Abbas and Mahdi [80]; Chong and Low } \\
\text { [84] }\end{array}$ \\
\hline Project management & $\begin{array}{l}\text { Jabbari and Ghorbani [85]; Khosravi et al. [86]; Marín et al. [87]; } \\
\text { Newaz et al. [88,89]; Pandit et al. [90] }\end{array}$ \\
\hline Crew relationship & Debrah and Ofori [52] \\
\hline Safety climate & Li [59]; Pandit et al. [90]; Probst et al. [91] \\
\hline Company size & $\begin{array}{l}\text { Lin and Mills [92]; Dong et al. [93]; Merchant, Lind, Kelly and Hall } \\
\text { [32]; Arquillos, Romero and Gibb [67] }\end{array}$ \\
\hline Subcontract & Debrah and Ofori [52]; Toole [62]; Awwad et al. [94] \\
\hline Old-style construction methods & Chun et al. [95] \\
\hline \multicolumn{2}{|r|}{ Weather } \\
\hline Hot summer/extreme weather & Navon and Kolton [96]; Chan [47]; Hu et al. [79]; Zhang et al. [97,98] \\
\hline Tight schedule & Debrah and Ofori [52] \\
\hline Site condition & $\begin{array}{l}\text { Gibb, Lingard, Behm and Cooke [83]; Lingard, Blismas, Harley, } \\
\text { Stranieri, Zhang and Pirzadeh [60]; Ning et al. [99] }\end{array}$ \\
\hline Small projects & Cakan et al. [100] \\
\hline Project complexity, construction & Choi [101]; Chockalingam and Sornakumar [102]; Shin et al. [103]; \\
\hline method/work condition & Lingard, Blismas, Harley, Stranieri, Zhang and Pirzadeh [60] \\
\hline Mega project & Shin et al. [104] \\
\hline \multicolumn{2}{|r|}{ Legal system } \\
\hline Regulations and enforcement & Chockalingam and Sornakumar [102]; Chan et al. \\
\hline \multicolumn{2}{|r|}{ Economic } \\
\hline Piece rate & Debrah and Ofori [52] \\
\hline Low construction cost & Xinyu and Jimmie [105] \\
\hline Low spending on safety & Debrah and Ofori [52] \\
\hline Firms' profitability & Forteza et al. [106] \\
\hline \multicolumn{2}{|l|}{ Proximal factor } \\
\hline Barriers & Winge and Albrechtsen [107]; Ale et al. [108] \\
\hline Bricklayers and building laborers & Suárez-Cebador et al. [109] \\
\hline Buried/suffocated by materials & $\begin{array}{c}\text { Ale, Bellamy, Baksteen, Damen, Goossens, Hale, Mud, Oh, } \\
\text { Papazoglou and Whiston [108] }\end{array}$ \\
\hline Caught in or between objects & $\begin{array}{l}\text { Zhang, Fleyeh, Wang and Lu [97]; Ale, Bellamy, Baksteen, Damen, } \\
\text { Goossens, Hale, Mud, Oh, Papazoglou and Whiston [108] }\end{array}$ \\
\hline Chemical substance & Zhang, Fleyeh, Wang and Lu [97] \\
\hline Collapse & Zhang, Fleyeh, Wang and Lu [97] \\
\hline Electrical shock & $\begin{array}{c}\text { Suárez-Cebador, Rubio-Romero and López-Arquillos [109]; Ale, } \\
\text { Bellamy, Baksteen, Damen, Goossens, Hale, Mud, Oh, Papazoglou } \\
\text { and Whiston [108] }\end{array}$ \\
\hline Equipment & Ning, Qi and Wu [99] \\
\hline Explosion/fire & $\begin{array}{l}\text { Zhang, Fleyeh, Wang and Lu [97]; Ale, Bellamy, Baksteen, Damen, } \\
\text { Goossens, Hale, Mud, Oh, Papazoglou and Whiston [108] }\end{array}$ \\
\hline Excavation and stabilisation & Baniassadi et al. [110] \\
\hline
\end{tabular}


Table 1. Cont.

\begin{tabular}{|c|c|}
\hline Construction Accidents Factors & Literature \\
\hline \multicolumn{2}{|l|}{ Proximal factor } \\
\hline Fall from a height & $\begin{array}{l}\text { Chi, Chang and Ting [37]; Dong, Fujimoto, Ringen and Men [93]; } \\
\text { Socias-Morales, Chaumont Menéndez and Marsh [38]; Winge and } \\
\text { Albrechtsen [107]; Ale, Bellamy, Baksteen, Damen, Goossens, Hale, } \\
\text { Mud, Oh, Papazoglou and Whiston [108] }\end{array}$ \\
\hline Fall from the same level & Antwi-Afari and Li [111]; Zhang, Fleyeh, Wang and Lu [97] \\
\hline Hit by falling objects & $\begin{array}{c}\text { Fass, Yousef, Liginlal and Vyas [42]; Ning, Qi and Wu [99]; Ale, } \\
\text { Bellamy, Baksteen, Damen, Goossens, Hale, Mud, Oh, Papazoglou } \\
\text { and Whiston [108] }\end{array}$ \\
\hline Hit by moving objects & $\begin{array}{l}\text { Hinze et al. [112]; Aneziris, Papazoglou, Mud, Damen, Bellamy, } \\
\text { Manuel and Oh [41]; Aneziris, Papazoglou, Mud, Damen, Bellamy, } \\
\text { Manuel and Oh [41]; Chinniah [40]; Ale, Bellamy, Baksteen, Damen, } \\
\text { Goossens, Hale, Mud, Oh, Papazoglou and Whiston [108] }\end{array}$ \\
\hline Inattentional blindness & Liao and Chiang [113] \\
\hline Overexertion & Nath et al. [114] \\
\hline $\begin{array}{l}\text { Poor materials (including waste) } \\
\text { handling }\end{array}$ & Irumba [65]; Ning, Qi and Wu [99] \\
\hline Poor visibility & Arditi et al. [115]; Arditi et al. [115] \\
\hline Roofing & Newaz, Davis, Jefferies and Pillay [89] \\
\hline Structural failure & Hintikka [116] \\
\hline Technical failure & Raviv et al. [117] \\
\hline \multicolumn{2}{|r|}{ Time } \\
\hline 10:00-11:00 and 15:00-16:00 & Shao et al. [118] \\
\hline Afternoon & Gurcanli and Mungen [119]; Ahmad, Iraj, Abbas and Mahdi [80] \\
\hline Night time & Arditi, Ayrancioglu and Jingsheng Shi [115] \\
\hline Monday & Arquillos, Romero and Gibb [67]; Shao, Hu, Liu, Chen and He [118] \\
\hline July/August & Shao, $\mathrm{Hu}, \mathrm{Liu}, \mathrm{Chen}$ and $\mathrm{He}$ [118] \\
\hline Traffic & Zhang, Fleyeh, Wang and Lu [97] \\
\hline
\end{tabular}

Note: An extended and modified version of [120]).

Although there exists literature which covers construction safety in general and specific types of projects—such as road, rail, and tunnel—little research has been carried out in relation to high-rise buildings. This may be because most buildings around the world are low-rise. Moreover, as property management has not been considered that important in the past, DSR projects are also understudied, not to mention the ranking of the relative safety risks in these projects. Nevertheless, an investigation of these causes could provide insight for drafters of legal and safety policy, as well as the sustainability of these projects. Thus, we intend to take the following measures:

- Compare the causes of accidents in new building and DSR projects;

- Construct safety indices for both types of project for ranking the relative importance of factors that lead to accidents on sites;

- Study whether the generation gap, long working hours, and skyscrapers in Hong Kong are attributed to the occurrence of construction accidents.

\subsection{Court Cases}

Unlike the labour inspection data as shown in Appendix A [121], slip, trip, or fall on same level; injured whilst lifting or carrying; and striking against or struck by moving object are the most common causes of accidents from 2006 to 2017, the majority of the construction accidents that end up in court are related to falls from a height, or being struck by falling or moving objects. Judges often suggest that employers, contractors, and subcontractors are the major stakeholders liable for accidents. For example, they fail to provide a safe working platform, leading to a fall from height. Thus, whether workers work in a high-rise or a low-rise building is irrelevant. Concerning the risk of being struck by moving objects, the failure to provide proper machinery and/or other equipment constitutes a major 
cause of accidents. Besides, being struck by a falling object is often caused by an unsafe working environment, dangerous behaviours, and carelessness. Numerous judges have also revealed that material agents, construction personnel, and poor working environments jointly lead to accidents. Among them, a poor working environment, which reflects the nature of the construction project or procedure, is a particularly major influencing factor of accidents.

Regarding the differences between new building and DSR projects, the likelihood of being struck by moving or falling objects in the former is higher than that for the latter. However, slightly higher injury rates due to falling from a height are recorded for DSR projects than for new building construction (Figure 1).

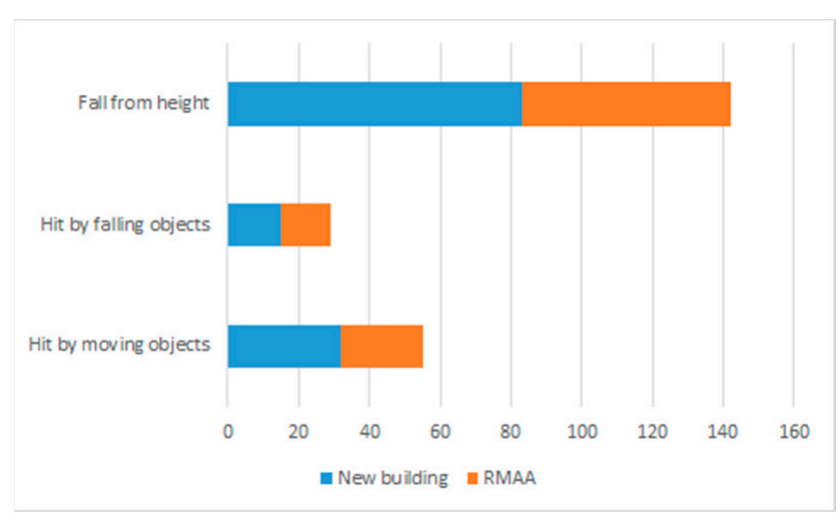

Figure 1. Coding results in new skyscraper and DSR projects.

\subsubsection{Court Cases Analysis Method-Tree Map}

Court case records of falls from a height are colour-coded and counted, and stop words are used to remove irrelevant words. The results are then visualised in the form of a tree map: a two-dimensional space-filling approach where each entity is a rectangle and the area is proportional to an attribute such as node size [122]. Different colours or grey shading are used within each region for visual clarity and represent different types of entities [123]. If words are in larger areas, this shows that they occur more frequently. There are three categories in general:

- Material agents, i.e., the materials which are linked with the accidents, e.g. people from the ladder, and the word 'ladder' is marked in green;

- Time when the accident happened is coded in yellow;

- Injured parts of the body, such as foot, head, knee are in white; and

- Physical activities when the accidents happened are represented by a blue colour (Figure 2).

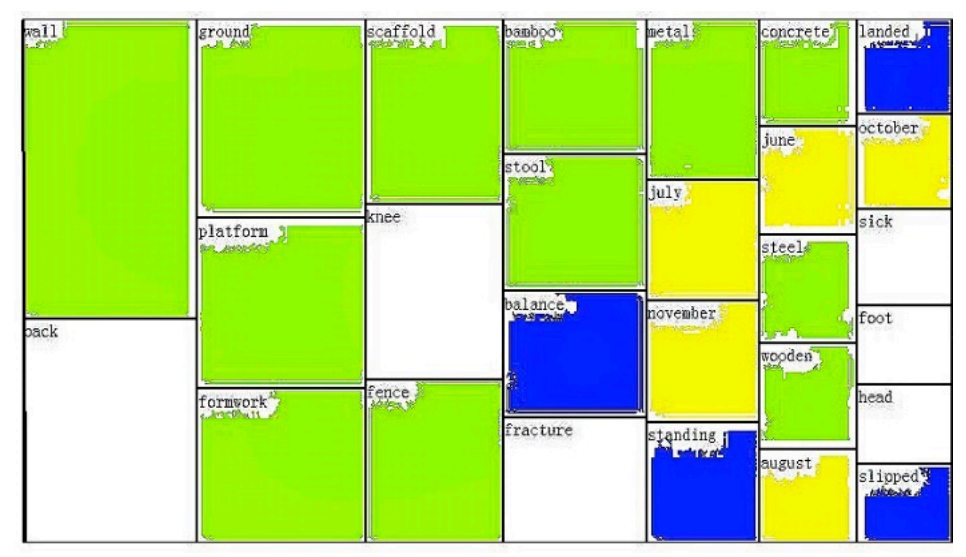

Figure 2. Cont. 


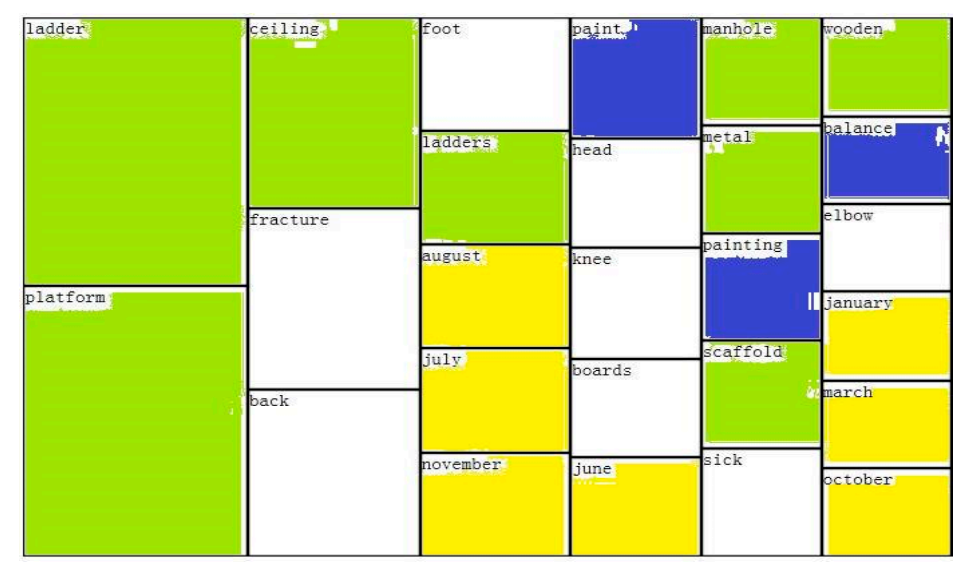

Figure 2. Fall from a height in new building (top) and DSR (down) projects.

\subsubsection{Results}

\section{(I) Falling from a Height}

As shown in the yellow tiles of Figure 2 below, most accidents occurred in the summer and winter. We speculate that extreme weather led to accidents. The green area shows that common material agents which are associated with accidents include platform, floor, ground, fence, wall, scaffolding, bamboo, metal, stool, road, concrete, formwork, wooden, manhole, pipe, slab, boards, steel, and ladder. Whilst we may believe that falling from a height refers to a fall from a high elevation, it is far more common to fall from a height of several feet. Besides this, dangerous work platforms such as fences, walls, and scaffolding always account for construction accidents related to working on external walls, setting up pipes or manholes outside and decorating ceilings, which constitute major construction activities attributed to injuries (Figure 2).

The most common injury-related physical activities included losing one's balance, slipping, and simply standing, as shown in the blue squares in Figure 2. To complete complex or intricate tasks, dangerous behaviours are sometimes necessary, such as standing on an unsafe platform, and can cause a loss of balance. Most victims incurred back injuries due to landing on the ground as per the white squares in the tree map. Additionally, when workers fell from a height, many landed on, or were struck by, other objects, such as collapsing ladders.

In DSR projects, workers often fall from a ladder or a platform, leading to bone fractures. With regard to new building projects, some workers lose their balance and fall from a height next to a wall, resulting in substantial back injuries.

\section{(II) Being Struck by Moving Objects}

Many workers are struck by moving metal during DSR projects, as indicated in the green area of the tree map; other injuries are caused by cuts from sharp blades, leading to lacerated or amputated fingers. In contrast, workers on new skyscraper projects most often sustain injuries from being struck by overhead cranes, as illustrated in the green area of the tree map, and/or by moving objects while dumping or cutting, indicated by the blue squares; they may also hurt their head and shoulder, as illustrated in the white squares of the Figure 3 tree map. 

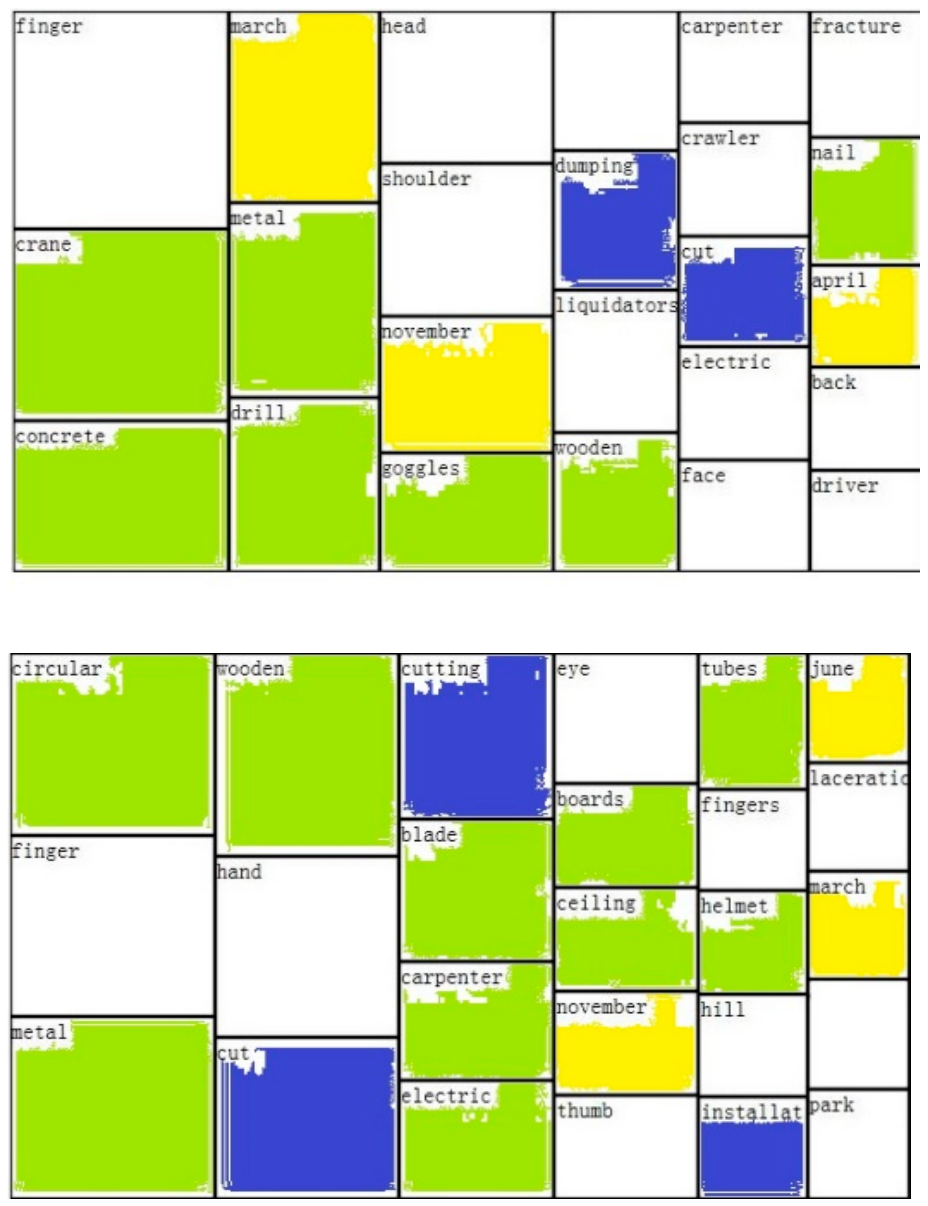

Figure 3. Hit by moving objects during new building (top) and DSR (down) projects.

(III) Being Struck by Falling Objects

During new building projects, court cases reveal that many victims are hit by falling metal, as shown in the green squares, while they are striking, lifting, installing, loading, and casting something, as indicated by the blue areas of the tree map below. Many of these come across as head injuries, followed by shoulders, legs, and eyes. Similar to new building works, most workers are struck by metal during DSR projects, and many of these instances happened in March, as per the yellow squares in the Figure 4 tree map.

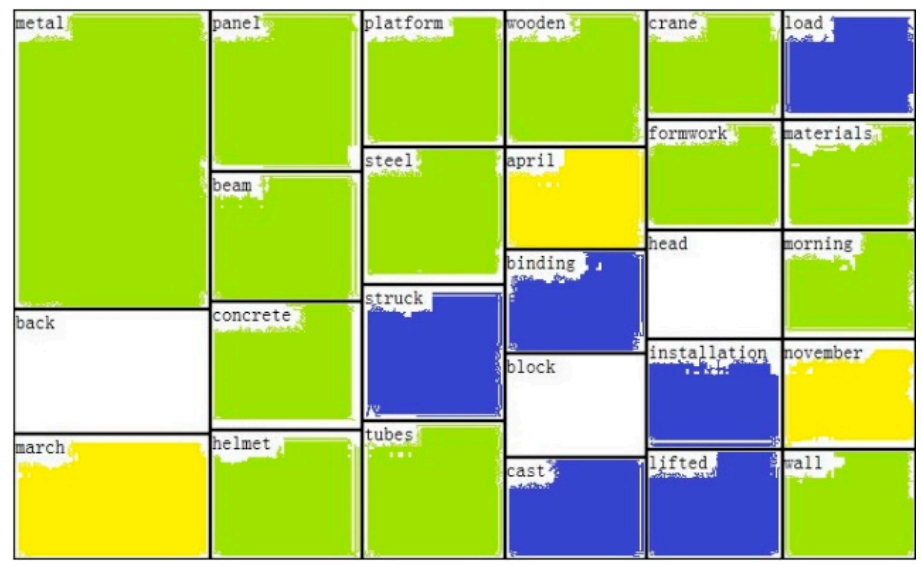

Figure 4. Cont. 


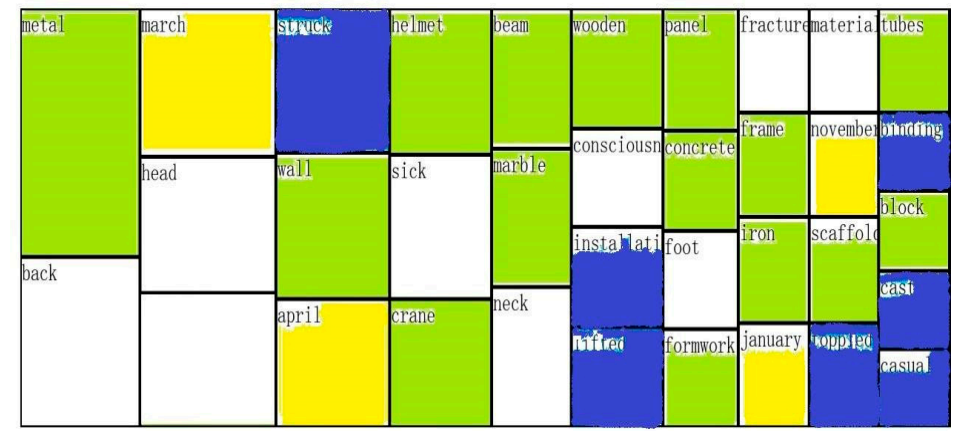

Figure 4. Hit by falling objects during new building (top) and DSR projects (down).

\section{(IV) Summary of the Court Cases}

Whilst the major consequences of being struck by moving objects and falling objects are head injuries, many victims sustain back injuries after falling from a height, the predominant material agents for which include working platforms and metallic objects. Many falls from a height are caused either by a loss of balance or being struck by falling objects while cutting and installing items. Table 2 summarises the differences between falling from a height, being struck by moving objects, and being struck by falling objects. Whilst the major consequences of being hit by moving objects and falling objects are head injuries, many victims who fall from a height also sustain back injuries.

Table 2. The most frequent and the second most frequent material agents, consequences, month, and physical activities during accidents.

\begin{tabular}{|c|c|c|c|}
\hline Frequency & Fall from a Height & Hit by Moving Objects & Hit by Falling Objects \\
\hline \multicolumn{4}{|c|}{ Consequences } \\
\hline The most frequent & Back & Head & Head \\
\hline \multicolumn{4}{|c|}{ Material agents } \\
\hline The most frequent & Platform & Metal & Metal \\
\hline The second most frequent & Floor & Machine & Wall \\
\hline \multicolumn{4}{|c|}{ Physical activities } \\
\hline The most frequent & Lost balance & Cut & Struck by \\
\hline The second most frequent & Slipped & Spray & Installation \\
\hline \multicolumn{4}{|c|}{ Month } \\
\hline The second most frequent & July / June & November & April \\
\hline
\end{tabular}

Table 3 illustrates the differences between new building and DSR projects. Many of the accidents which happen on new building sites are related to tower cranes, while those during DSR projects are linked with the circular saw in hit by moving object cases. New building workers fall from a height due to losing balance, but the DSR project workers fall from a height when they are painting.

Table 3. Comparison between new building and DSR when accidents occur.

\begin{tabular}{ccccc}
\hline $\begin{array}{c}\text { Physical Activities } \\
\text { When Accidents Occur }\end{array}$ & $\begin{array}{c}\text { Material Agents } \\
\text { Involved }\end{array}$ & $\begin{array}{c}\text { Parts of Body } \\
\text { Injured }\end{array}$ & $\begin{array}{c}\text { Physical Activities } \\
\text { when Accidents Occur }\end{array}$ & Month \\
\hline New building & Wall & Fall from a height & Back \\
DSR & Ladder & $\begin{array}{c}\text { (Bone) fracture } \\
\text { Hit by falling objects }\end{array}$ & $\begin{array}{c}\text { Balance } \\
\text { Paint }\end{array}$ & $\begin{array}{c}\text { July } \\
\text { August }\end{array}$ \\
New building & Metal & Back & Metal & March \\
DSR & Wall & Foot & MA & March \\
New building & Crane & Hit by moving objects & Finger & Dumping \\
DSR & Circular saw & Finger & Cut & March \\
& & & & November \\
\hline
\end{tabular}




\subsection{Semi-Structured Interviews}

The interviews were conducted with interviewees possessing an average of at least 18 years of work experience. Most interviewees agreed that accidents are caused by falls from a height and being struck by moving or falling objects, which is consistent with the records from the court cases. A safety manager in a foundation company suggested that falling from a height is the most predominant cause of accidents. Although these causes vary between new building constructions and DSR projects, they share common factors, as per a safety officer, who stated that "[concerning] working at height ... most workers fall from ladders rather than falling from the new buildings to the ground."

\subsubsection{Project Management and the Generation Gap}

The interviewees agreed that poor management is a major cause of accidents. Good collaboration among construction personnel is important. In new building projects, if experienced workers act as safety mentors or send safety alerts to less experienced workers, the safety conditions will improve. In DSR projects, cooperation refers to the interactions between supervisors and front-line workers, as the safety awareness of the personnel working on a DSR project is lower than that of the personnel working on a new skyscraper construction.

Concerning new skyscraper projects, a safety officer in a listed foundation company with 15 years of work experience suggested that "the collaboration problem between experienced workers and rookies is a major cause. Since the ageing problem in the construction industry is serious, coupled with the generation gap, it is difficult for new personnel to find an experienced mentor." As new building construction is challenging, it requires experienced, high-quality workers. A construction worker in a foundation company with 40 years of work experience conceded that "uncooperative teamwork plays an important role in accidents."

\subsubsection{Housekeeping}

Poor on-site housekeeping is also attributed to accidents. For example, workers can easily fall into an uncovered hole. Whilst many interviewees suggested that housekeeping is not a major cause of accidents on new building projects, housekeeping does constitute a major cause of accidents during DSR projects, the sites of which may contain several materials, tools, and kinds of equipment and rubble that represent potential safety hazards if stored in a disorderly and untidy manner.

A structural engineer at a DSR company with 29 years of work experience suggested that "all the tools and equipment are usually stored in a good location at the beginning. Accidents caused by poor housekeeping are rare." A director at a DSR company and an apprentice of a listed foundation company with 40 years of work experience expressed concerns that "if electrical wires are in disarray, workers may stumble or be hit by flying objects." Moreover, a safety manager at a listed foundation company with 26 years of work experience proposed that "manual lifting and other minor injuries [are the most important causes of accidents]. As most DSR projects involve manual work, most injuries are related to manual lifting. In addition, the housekeeping in DSR work areas is so poor that injuries may occur."

\subsubsection{Safety Measures}

Interviewed construction practitioners doubted whether sufficient training is provided for new skyscraper projects, specifically with regard to the use of machinery and working at heights. With regard to DSR projects, the interviewees expressed more concern about the availability of safe working environments and the fact that workers are often employed on multiple projects and different jobs simultaneously. 
(I) New Building Projects

A government-employed structural engineer with 16 years of work experience advised that "if the managerial staff have concerns about the safety, the situation will improve ... if the management is concerned about the hardware used for safety measures, they will provide better safety measures and equipment."

\section{(II) DSR Projects}

A project manager at an architectural firm suggested that "since the scale of DSR work is smaller than that of new buildings, they pay less attention to management. As DSR projects are simpler than new buildings, workers have a lower safety awareness. Increasing safety awareness via training is important."

A chairman of the Employees General Union with over 30 years of work experience proposed that "how to arrange DSR projects with many small jobs and providing a safe working platform are important. If the manager does not arrange the electricity job well or if the manager gives insufficient information to the workers, accidents happen easily."

A safety officer at a listed foundation company with 20 years of work experience stated that "workers' safety awareness is a major factor that leads to construction accidents. As DSR projects are smaller than new building construction projects, subcontractors may not provide sufficient training for workers." A secretary for a construction association with over 30 years of work experience stated that "most DSR projects are not as complex as building a new building. Thus, the workers have poor education and safety awareness."

\subsubsection{Finance}

The interviewees stated that having sufficient funding predetermines the provision of safety equipment and training. This is because the funding sources of DSR projects are limited, as most are carried out by small-scale companies that tend not to invest in safety. Moreover, many companies hire part-time labour to cut costs, although the mobility of part-time labour is higher than that of full-time labour, resulting in incomplete training and an outflow of skilled labour. Nevertheless, some projects require specialised skills and knowledge.

A secretary for a construction association with over 30 years of work experience stated that "most DSR companies are small with insufficient training and inadequate protective equipment for workers." Furthermore, an international labour organisation head with 37 years of work experience suggested that "large companies have money for training or safety tools, while small-scale builders do not. Thus, the workers' training and knowledge are insufficient in DSR projects."

Concerning new building projects, a director of a safety consultancy company suggested that "when the client or developer's financial support allocated to contractors is limited, the contractors may not provide sufficient safety measures for the workers." A chairman of the Employees General Union with over 30 years of work experience conceded that "as the labour mobility in the construction industry is quite serious, the safety training and experience accumulated for work are insufficient. Part-time labour increases safety hazards."

\subsubsection{Construction Safety Awareness}

Most experts argue that the dangerous activities performed by workers lead to accidents, and low safety awareness accounts for construction accidents. The personnel represent the most difficult factor to control. In addition, a lack of professional knowledge largely accounts for accidents; this is especially true for DSR projects, in which the workers' safety awareness is lower than that of workers on new building projects. Moreover, construction personnel play an important role in helping workers develop safety awareness and reduce hazards. For example, if a project designer considers safety issues during the project design and carries them through to the complex construction stage, workers 
will no longer engage in dangerous activities. If the foremen possess sufficient safety knowledge and bear responsibility, they will warn workers of potential hazards. Clients who possess a strong sense of safety awareness keep a firm watch over workers' activities. Thus, various construction stakeholders, negligence, and workers' safety experience can all affect the safety performance.

\section{(I) New Building Projects}

A safety officer at a listed foundation company with 20 years of work experience suggested that "the most important cause of accidents is the human factor. Negligence and carelessness lead to accidents. Sometimes, even when adequate safety equipment is provided, they do not wear them because they are uncomfortable and they think that the equipment is unnecessary ... if workers pay more attention to safety rather than time, the number of accidents will decrease."

\section{(II) DSR projects}

A secretary for a construction association with over 30 years of work experience suggested that "most DSR projects are less complicated than new building projects. Many workers have a poor educational background and poor safety awareness." A foreman at a listed foundation company suggested that "the safety awareness of workers is low...workers always believe that there is a low safety risk during DSR projects."

\subsubsection{Working Environment}

Most interviewees argued that construction sites in Hong Kong are small with insufficient space for storage and the operation of machinery and equipment. Workers are thus at a higher risk of being struck by moving objects and machines. These complex work environments-e.g., the lack of adequate safety exits in old buildings-account for accidents. Extreme weather can also lead to heat stress and slippery surfaces; however, this affects new buildings more, as new constructions require additional outdoor tasks.

A director of a safety consultancy company proposed that "heat stress worsens a worker's [health]." Moreover, a project manager at an architectural consultancy firm commented that "it is necessary to remove stagnant water...water potentially leads to workers falling due to sliding." In addition to this, a safety officer at a listed foundation company with over 15 years of work experience stressed that "construction sites are small; it is difficult to accomplish any construction, and the lack of space easily leads to accidents. Machines or other objects easily hit workers on small sites." Regarding DSR projects, a construction worker with 40 years of experience stated that "after it rains, bamboo is wet. Workers easily slip and fall."

\subsubsection{Legal Aspects}

Although new building constructions exhibit better regulations and supervision, workers consider the time to be their top priority rather than safety. While some companies reserve time for breaks, extensive overtime impairs concentration, leading to accidents. Some interviewees suggested that overtime should be ratified via legislation. Compared with new building projects, many DSR projects are poorly supervised with a lack of formal procedures. Consequently, workers take shortcuts that lead to accidents.

A safety manager at a listed foundation company with 26 years of work experience stated regulation is one major factor which affects new building construction safety: "since the fire regulations are not strict when a new building is constructed...frequent checking is neglected, and the safety awareness is low." In addition, a project manager at an architectural consultancy company suggested that "[workers] need to follow regulations, e.g., wearing a safety helmet, a vest, and other safety equipment." 
A safety manager at a listed foundation company with 26 years of work experience suggested that regulation is one of the factors that affect DSR safety at work "the regulations are not strict. [Although] there are more DSR projects...the government tends to rely on a company's self-discipline."

\subsubsection{Tight Schedules and Excessive Overtime}

Excessive overtime is one factor that affects the safety performance of both DSR and skyscraper projects. The head of an international labour organisation with 37 years of work experience suggested that "the rush to complete a project or work in overtime can lead to accidents ... A very reputable company rushed to meet the deadline, the crane fell and killed workers ... If the schedule is tight and workers have insufficient training, accidents easily happen." One safety officer stated that many workers work overtime, which affects their safety performance.

\subsubsection{Safety Training}

Safety training is one of the major factors that affect safety during new building construction projects. A project manager at an architectural company suggested the following: "once you have adequate training, such as training for the safe operation of a special machine, wearing a safety belt and paying attention when working at heights, on-site injuries can be substantially reduced." A department head at an international labour organisation with 37 years of work experience also stated the following: "workers who have insufficient training ... are particularly hazardous [if they] are needed to construct special projects."

During DSR projects, safety training is also an indispensable component. A safety trainer suggested that "if the manager does not provide a safe working platform, a simple tool such as a ladder may lead to a fatal accident ... training is important in DSR projects because workers often work on different jobs at the same time ... I remember that a casual worker without any relevant training got an electric shock while doing electrical work."

\subsection{AHP Results}

By examining the literature, court cases, and interview responses, we have identified some important factors that lead to accidents. Five major criteria were included in the hierarchy: project management, construction personnel, working environment, legislation and legal enforcement, and financial concerns. We then constructed the AHP model, as shown in Figure 5. Respondents were asked to compare the relative importance of the factors that affect the safety risks. For example, project management and construction personnel were at the first level, and the comparison between poor communication and poor housekeeping was at the second level. Details of the questionnaire can be found in Appendix B.

The AHP questionnaire was distributed to 53 contractors on the Hong Kong Development Bureau's list of Approved Contractors for Public Works and 74 minor works contractors on the Buildings Department's list of Registered Minor Works Contractors, in addition to 10 individual safety consultancy companies and government departments in Hong Kong. We received responses from 21 experts on new building projects and 37 experts on DSR projects. Similar to Ghimire and Kim [31], surveys were conducted via face-to-face meetings with experts in the field who had worked over 5.5 years, and requests were sent via e-mail. The safety indices in the new skyscraper and DSR categories meet the consistency criterion (below 0.1). The combined weight of the new building and DSR projects is shown in Table 4. 


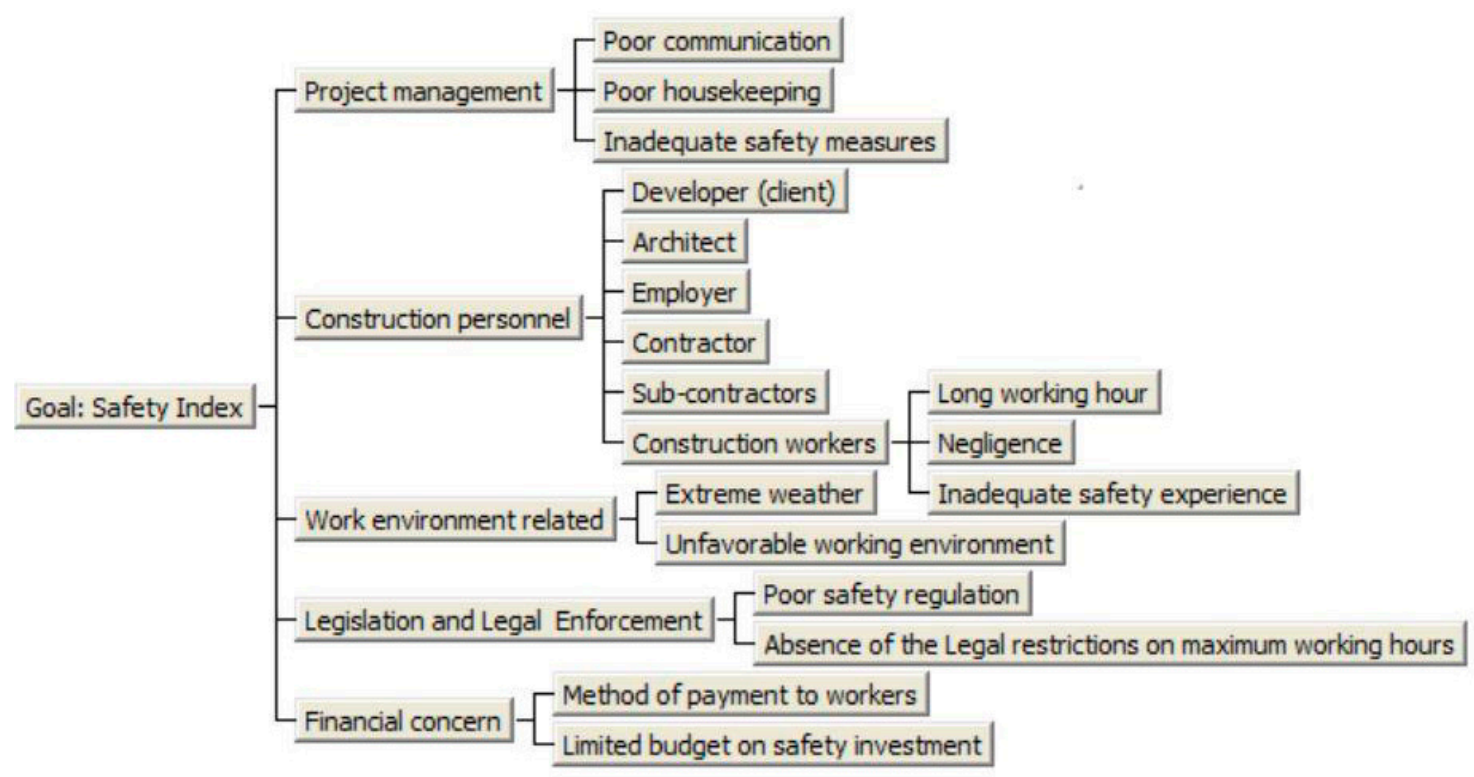

Figure 5. AHP model.

Pair-wise comparisons for new skyscrapers showed that limited budget for safety (0.722), followed by project characteristics (0.671) and regulation (0.670), were the most important causes that affect site safety. Nevertheless, the DSR score depicted that poor safety regulation ranked first (0.599), payment approach piece rate ranked second (0.561), and extreme climatic condition ranked third (0.52) (Table 4). 
Table 4. New buildings and DSR's safety indices.

\begin{tabular}{|c|c|c|c|c|c|c|c|}
\hline Criteria & $\begin{array}{c}\text { Weights } \\
\text { (New Building) }\end{array}$ & $\begin{array}{c}\text { Ranks } \\
\text { (New Building) }\end{array}$ & $\begin{array}{l}\text { Weights } \\
\text { (DSR) }\end{array}$ & $\begin{array}{l}\text { Ranks } \\
\text { (DSR) }\end{array}$ & Sub-Criteria & $\begin{array}{c}\text { Weights } \\
\text { (New Building) }\end{array}$ & $\begin{array}{l}\text { Weights } \\
\text { (DSR) }\end{array}$ \\
\hline \multirow{3}{*}{$\begin{array}{c}\text { Project } \\
\text { Management }\end{array}$} & \multirow[t]{3}{*}{0.205} & \multirow[t]{3}{*}{ 2nd } & \multirow[t]{3}{*}{0.205} & \multirow[t]{3}{*}{$3 \mathrm{rd}$} & Poor cooperation & 0.268 & 0.379 \\
\hline & & & & & Poor housekeeping & 0.254 & 0.284 \\
\hline & & & & & Inadequate safety measures (including training) & 0.479 & 0.337 \\
\hline \multirow{9}{*}{$\begin{array}{l}\text { Construction } \\
\text { Personnel }\end{array}$} & \multirow{9}{*}{0.176} & \multirow[t]{9}{*}{5 th } & \multirow[t]{9}{*}{0.252} & \multirow[t]{9}{*}{$1 \mathrm{st}$} & Developer & 0.089 & 0.153 \\
\hline & & & & & Architect & 0.129 & 0.125 \\
\hline & & & & & Employer & 0.162 & 0.160 \\
\hline & & & & & Contractor & 0.217 & 0.199 \\
\hline & & & & & Sub-contractors & 0.213 & 0.189 \\
\hline & & & & & Construction workers & 0.191 & 0.175 \\
\hline & & & & & Long working hours & 0.201 & 0.312 \\
\hline & & & & & Worker negligence & 0.344 & 0.363 \\
\hline & & & & & Inadequate safety experience & 0.455 & 0.325 \\
\hline Working & \multirow[t]{2}{*}{0.194} & \multirow[t]{2}{*}{$3 \mathrm{rd}$} & \multirow[t]{2}{*}{0.163} & \multirow[t]{2}{*}{ 4th } & Extreme climatic conditions & 0.329 & 0.520 \\
\hline Environment & & & & & Project characteristics & 0.671 & 0.480 \\
\hline Legislation and & 0.238 & \multirow[t]{2}{*}{1 st } & \multirow[t]{2}{*}{0.161} & \multirow[t]{2}{*}{5 th } & Poor safety regulation & 0.670 & 0.599 \\
\hline Legal Enforcement & \multirow{3}{*}{0.187} & & & & Absence of maximum working hours regulation & 0.330 & 0.401 \\
\hline \multirow{2}{*}{ Financial Concern } & & 4th & 0.219 & 2nd & Piece-rated & 0.278 & 0.561 \\
\hline & & & & & Limited budget for safety & 0.722 & 0.439 \\
\hline
\end{tabular}




\section{Discussion and Conclusions}

\subsection{Causes of Construction Accidents under Different Types of Evidence}

While the systematic review of the previous literature suggested that accidents are caused by a combination of distal and immediate factors, these literary sources did not compare the differences between DSR and new building projects. Court cases revealed that most of the accidents happened due to fall from a height, and being struck by moving or falling objects. In hit by moving object cases, most accidents happened on new building sites due to tower crane failure, while those DSR projects were linked with the circular saw. New building workers fell from a height due to losing balance, although the DSR project workers fell from a height when they were painting.

The interviews revealed that (1) the collaboration problem between experienced workers and rookies is a major construction accident cause in new building projects, (2) the ageing problem in the construction industry imposes difficulty for new personnel to find an experienced mentor, and (3) loose regulation increases the safety risks on sites. While many of us may consider the contractors who work for the new building projects to be richer with relatively more funding for the project, and see DSR contractors as far poorer, limited budget for safety ranked first among the new building projects but not among the DSR projects.

All in all, the systematic review, interviews and the survey results considered both the distal and immediate factors that lead to construction accidents. Yet, judges focus more on the direct factors that lead to accidents.

\subsection{Policy, Practical, and Academic Implications}

Academically speaking, this research shows that the generation gap may pose difficulties in communication, and working overtime may lead to accidents, while the extremely long working hours could give rise to accidents at work. These two findings may open a new research agenda in other high-density developed cities with ageing population problems and long working hours. To the best of the authors' knowledge, the evidence-based practice research method has been adopted in clinical, public policy, social work, etc. to research both academic endeavours and practice. Indeed, the present study is the first of its kind, as it adopts the abovementioned method in construction safety research. We attempted to modify and adopt the evidence-based practice approach with (a) systematic review of peer-reviewed journal articles; (b) evidence obtained from court and safety officers' expertise; and (c) construction practitioners' perceptions. The purpose of all of this was to narrow the gap between research and practice which exists within various sources of evidence.

Practically speaking, the differences in the causes of accidents among new building and DSR projects indicated that there is a need for better fitting regulations and policies to replace the existing one-size-fits-all policies. Specific safety training should be provided to workers rather than relying on mandatory green card safety training. These results also provide insights into the facility management sector, which performs many refurbishment tasks every day but often considers these projects to be small scale and sees them as undermining the importance of occupational safety.

\subsection{Appraising Different Types of Evidence in Construction Safety}

In evidence-based practice, one important element is to appraise different types of evidence, as such different kinds of evidence have their benefits and drawbacks. In this research, the academic literature consulted covers various parts of the world regarding the distal and immediate factors that affect safety risks across time and locations. Yet, this literature fails to reveal the causes of Hong Kong's problems, including the extraordinarily long hours of work and the ageing workers. Judges have to study a wide range of evidence, such as the testimony, doctor's report, etc., before deciding on who is responsible for the accidents. Yet, not all of the cases end up in court; cases involving small compensation are usually not included. Evidence from interviews provides a detailed explanation of what causes accidents in the local context, but the number of respondents can be small, and some 
might argue that respondents may not tell the truth. However, this type of evidence does provide us with information which the labour report cannot, e.g., the causes of accidents in new building and DSR projects instead of numerical representations and statistics on the origins of accidents in general. Finally, a comparison of different types of factors that drive accidents can be eased by using the AHP, although the detailed rationale behind requires the interview to support. Our research illustrates the gap between research and practice, which can inform both sides of this difference and help open a dialogue between both sides in the future to narrow said gap, realising the beauty of evidence-based practice research (Table 5).

Table 5. Research evidence appraisal.

\begin{tabular}{|c|c|c|}
\hline Types of Evidence & Strengths of the Evidence & Weaknesses of the Evidence \\
\hline Systematic review of the literature & $\begin{array}{l}\text { It covers different parts of the } \\
\text { world regarding what causes } \\
\text { accidents over a long period and } \\
\text { many locations. }\end{array}$ & $\begin{array}{l}\text { It fails to cover the local context } \\
\text { phenomenon. }\end{array}$ \\
\hline Court cases & $\begin{array}{l}\text { Results are obtained after } \\
\text { examining all evidence. }\end{array}$ & $\begin{array}{l}\text { Not all the construction accident } \\
\text { cases end up in court. }\end{array}$ \\
\hline Interviews & $\begin{array}{l}\text { A detailed explanation of what } \\
\text { causes accidents in the local } \\
\text { context. }\end{array}$ & $\begin{array}{l}\text { The number of respondents can be } \\
\text { small and respondents may lie. }\end{array}$ \\
\hline AHP questionnaires & $\begin{array}{l}\text { Comparison of different types of } \\
\text { factors that drive accidents is easy } \\
\text { to see and interpret. }\end{array}$ & $\begin{array}{l}\text { A lack of detailed explanation of } \\
\text { the factors behind. }\end{array}$ \\
\hline Labour inspection report & $\begin{array}{l}\text { Highly-reliable data can be } \\
\text { obtained. }\end{array}$ & $\begin{array}{l}\text { It only reveals the immediate } \\
\text { factors that cause the accidents but } \\
\text { falls short of a study on the distal } \\
\text { factors that cause accidents. }\end{array}$ \\
\hline
\end{tabular}

Author Contributions: Conceptualization, R.Y.M.L. and K.W.C.; methodology, R.Y.M.L.; F.F.Z.; formal analysis, F.F.Z., R.Y.M.L.; resources, R.Y.M.L., K.W.C, F.F.Z.; data curation, R.Y.M.L. and F.F.Z.; writing, R.Y.M.L., F.F.Z. and K.W.C; visualization, F.F.Z.; supervision, R.Y.M.L.

Funding: This research was funded by Research Grant Council, Construction safety index for skyscrapers in Hong Kong: A Multi-criteria decision-making approach, UGC/FDS 15/E01/15; Willingness to share construction safety knowledge via Web 2.0, mobile apps and IoT, UGC/FDS15/E01/17; Ocular behaviour, construction hazard awareness, and an AI chatbot, UGC/FDS15/E01/18.

Conflicts of Interest: The authors declare no conflict of interest. 


\section{Appendix A}

Table A1. Causes of the accidents (cases which are reported to the Labor Department [121], fatal cases are in bracket ( ).

\begin{tabular}{|c|c|c|c|c|c|c|c|c|c|c|c|c|c|c|c|c|c|c|c|c|c|c|c|c|}
\hline Types of Accident & 2006 & & 2007 & & 2008 & & 2009 & & 2010 & & 2011 & & 2012 & & 2013 & & 2014 & & 2015 & & 2016 & & 2017 & \\
\hline Trapped in or between substances & 101 & $(1)$ & 68 & $(2)$ & 67 & & 93 & & 85 & & 106 & $(1)$ & 114 & (1) & 137 & & 205 & $(2)$ & 160 & $(1)$ & 158 & & 147 & $(3)$ \\
\hline Asphyxiation & 3 & (3) & 0 & & 3 & & 0 & & 0 & & 0 & & 0 & & 0 & & 1 & $(1)$ & 1 & $(1)$ & 0 & & 0 & \\
\hline Contact with electric discharge or electricity & 14 & & 10 & $(1)$ & 19 & (5) & 5 & & 7 & (1) & 6 & $(2)$ & 17 & (7) & 10 & & 12 & $(2)$ & 8 & (3) & 7 & (2) & 9 & \\
\hline Contact with hot substance or surface & 22 & & 18 & & 22 & & 21 & & 20 & & 20 & & 23 & & 13 & & 24 & & 20 & & 23 & & 19 & \\
\hline $\begin{array}{l}\text { Contact with moving equipment or object being } \\
\text { machined }\end{array}$ & 236 & & 198 & & 24 & & 199 & & 245 & $(2)$ & 216 & & 234 & & 216 & & 213 & & 230 & & 232 & & 193 & \\
\hline Drowning & 0 & & 1 & $(1)$ & 0 & & 1 & (1) & 0 & & 1 & $(1)$ & 0 & & 1 & (1) & 3 & (3) & 0 & & 0 & & 3 & (3) \\
\hline to explosion & 3 & & 2 & & 1 & & 4 & & 3 & & 9 & (1) & 4 & & 6 & & 2 & & 5 & & 3 & $(1)$ & 2 & \\
\hline Exposure to fire & 16 & & 12 & & 11 & & 8 & & 5 & & 11 & & 7 & & 4 & & 3 & $(1)$ & 6 & & 4 & & 13 & \\
\hline Exposure to or co & 20 & & 20 & & 24 & & 8 & & 7 & & 20 & & 20 & & 15 & & 24 & & 15 & & 22 & & 31 & \\
\hline Fall of person & 409 & $(10)$ & 366 & $(10)$ & 389 & $(8)$ & 400 & (15) & 407 & (6) & 390 & (10) & 429 & (15) & 439 & (18) & 374 & (7) & 380 & (9) & 351 & (8) & 381 & $(11)$ \\
\hline Injure & 7 & & 2 & & 1 & & 6 & & 2 & & 4 & & 1 & & 2 & & 4 & & 7 & & 8 & & 4 & \\
\hline Inju & 0 & & 1 & & 2 & & 1 & & 0 & & 1 & & 4 & (1) & 2 & (1) & 0 & & 0 & & 0 & & 0 & \\
\hline Inju & 228 & & 155 & & 99 & & 137 & & 104 & & 117 & & 96 & & 97 & & 106 & & 141 & & 122 & & 180 & \\
\hline Injur & 6 & & 8 & & 5 & & 6 & & 14 & & 7 & (1) & 7 & & 8 & & 12 & & 15 & & 14 & & 21 & \\
\hline Inji & 542 & & 590 & & 595 & & 57 & & 551 & & 606 & & 525 & & 490 & & 453 & & 677 & & 626 & & 724 & \\
\hline n same level & 632 & & 539 & & 584 & & 519 & & 581 & & 649 & & 738 & & 801 & & 882 & & 950 & & 1057 & & 1086 & \\
\hline Stepping on entity & 38 & & 33 & & 22 & & 19 & & 27 & & 30 & & 18 & & 6 & & 9 & & 11 & & 9 & & 21 & \\
\hline Striking against imm & 387 & & 324 & & 285 & & 220 & & 305 & & 280 & & 295 & $(1)$ & 311 & & 390 & & 382 & & 392 & & 447 & \\
\hline Striking agains & 613 & $(1)$ & 585 & & 517 & $(4)$ & 426 & (2) & 443 & & 522 & (3) & 551 & (2) & 612 & (2) & 646 & $(2)$ & 584 & $(1)$ & 586 & $(1)$ & 549 & $(3)$ \\
\hline Struck & 132 & (1) & 114 & (3) & 101 & (1) & 87 & (1) & 75 & & 73 & (3) & 56 & & 50 & (2) & 68 & (5) & 110 & (3) & 111 & & 113 & (2) \\
\hline Struc & 40 & & 33 & (1) & 38 & (3) & 37 & (2) & 23 & (2) & 25 & (2) & 19 & (1) & 21 & (2) & 28 & & 49 & (4) & 29 & (5) & 32 & \\
\hline Trapped & 5 & (1) & 13 & (2) & 10 & $(2)$ & 0 & & 1 & & 8 & (2) & 6 & & 5 & & 4 & & 2 & & 2 & & 7 & (3) \\
\hline Others & 45 & (3) & 43 & (17) & 46 & (13) & 51 & (20) & 60 & (15) & 87 & (20) & 88 & (16) & 86 & (11) & 110 & (15) & 110 & (21) & 104 & (15) & 132 & (26) \\
\hline Total & 3499 & $(20)$ & 3135 & (37) & 3087 & $7(36)$ & 2827 & (41) & 2965 & $(26)$ & 3188 & $3(46)$ & 3252 & $(44)$ & 3332 & (37) & 3573 & $3(38)$ & 3863 & $(43)$ & 3860 & $(32)$ & 4114 & $4(51)$ \\
\hline
\end{tabular}




\section{Appendix B AHP Questionnaire}

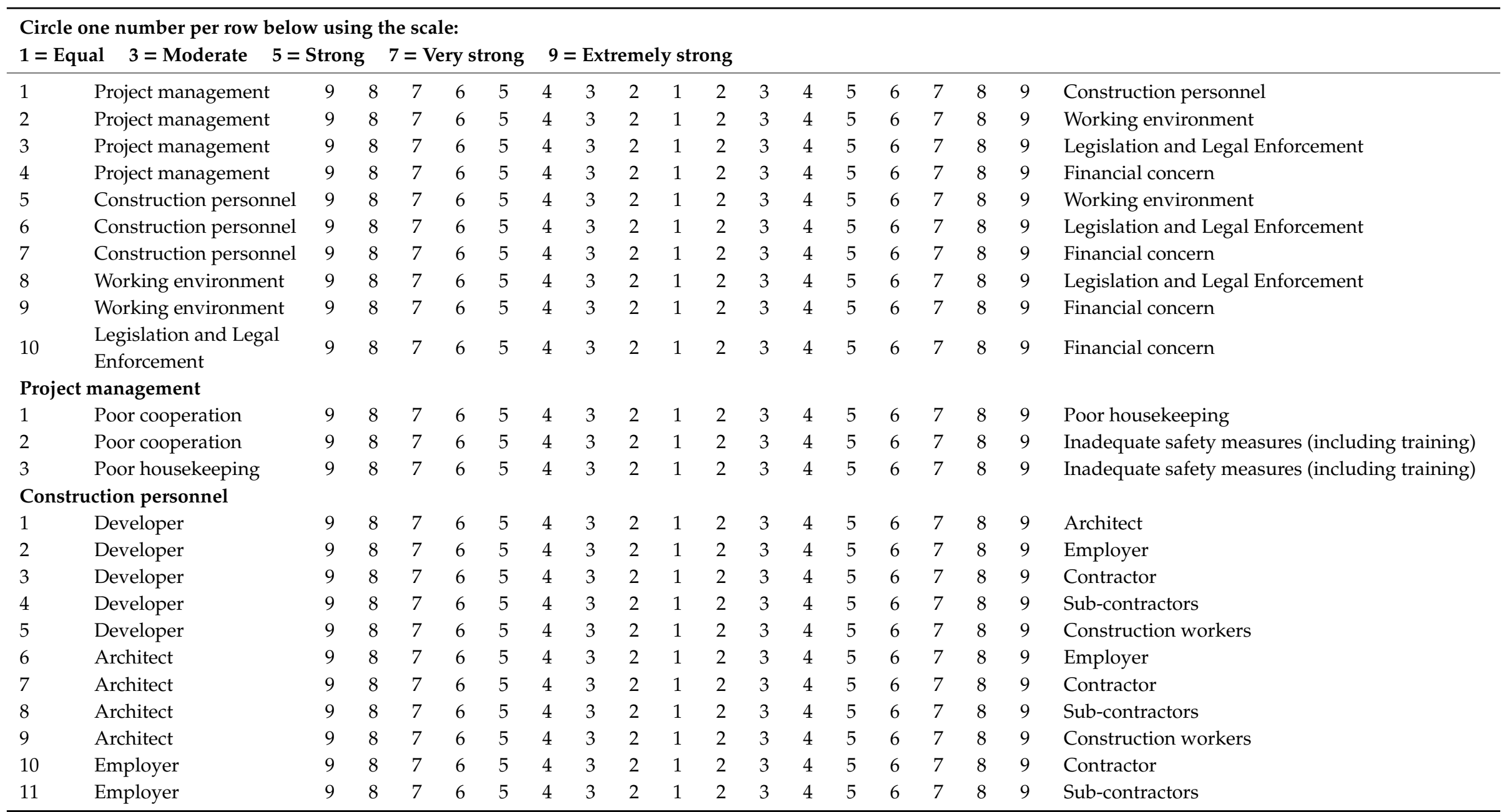




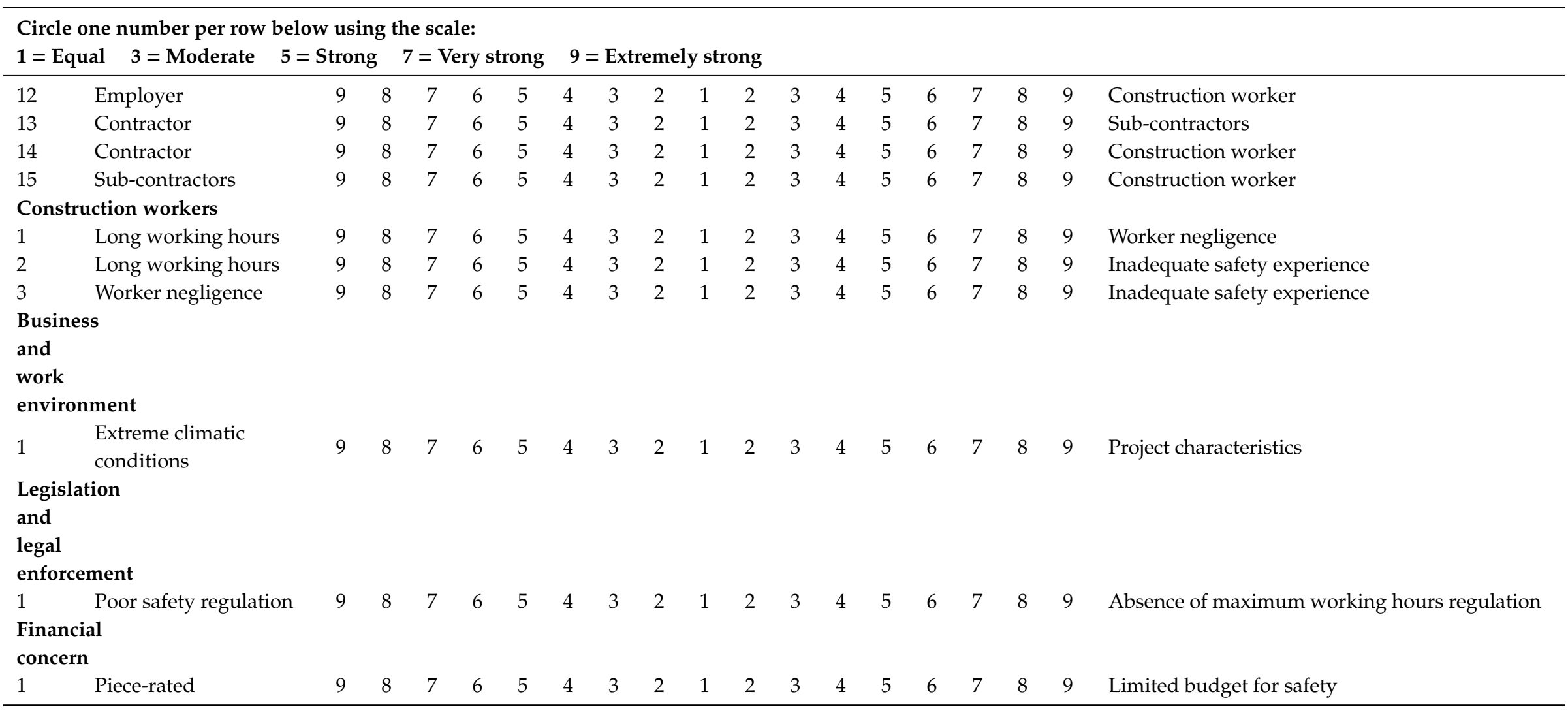




\section{References}

1. Wu, X.; Chong, H.-Y.; Wang, G.; Li, S. The influence of social capitalism on construction safety behaviors: An exploratory megaproject case study. Sustainability 2018, 10, 3098. [CrossRef]

2. Nawaz, W.; Linke, P.; Koç, M. Safety and sustainability nexus: A review and appraisal. J. Clean. Prod. 2019, 216, 74-87. [CrossRef]

3. Zhang, D.; Wei, B.; Rosen, M. Overview of an Engineering Teaching Module on Robotics Safety; Springer International Publishing: Cham, Switzerland, 2017; pp. $29-43$.

4. Census and Statistics Department of Hong Kong. Population. Available online: http://www.censtatd.gov.hk/ hkstat/sub/so20.jsp (accessed on 28 June 2017).

5. Barr, J. High rise buildings height. J. Real Estate Financ. Econ. 2010, 45, 723-753. [CrossRef]

6. Li, R.; Cheng, K.; Shoaib, M. Walled buildings, sustainability, and housing prices: An artificial neural network approach. Sustainability 2018, 10, 1298. [CrossRef]

7. RTHK. HK Has Longest Working Hours in the World. Available online: http://news.rthk.hk/rthk/en/ component/k2/1262299-20160525.htm?spTabChangeable=0 (accessed on 21 October 2018).

8. Jayantha, W.M.; Qian, Q.K.; Yi, C.O. Applicability of 'aging in place' in redeveloped public rental housing estates in hong kong. Cities 2018, 83, 140-151. [CrossRef]

9. Li, R.Y.M. Generation $x$ and $y$ 's demand for homeownership in hong kong. Pac. Rim Prop. Res. J. 2015, 21, 15-36. [CrossRef]

10. Nicholas, C.; Jamal, M.K.; Mohamed, F. The perceptions of contractor's and landlord's representatives in the refurbishment of tower blocks. Facilities 2013, 31, 521-541.

11. Shah Ali, A.; Nizam Kamaruzzaman, S.; Salleh, H. The characteristics of refurbishment projects in malaysia. Facilities 2009, 27, 56-65. [CrossRef]

12. Shayan, S.J.; Kiwanuka, F.; Nakaye, Z. Barriers associated with evidence-based practice among nurses in lowand middle-income countries: A systematic review. Worldviews Evid.-Based Nurs. 2019, 16, 12-20. [CrossRef]

13. Spring, B. Evidence-based practice in clinical psychology: What it is, why it matters; what you need to know. J. Clin. Psychol. 2007, 63, 611-631. [CrossRef]

14. Snibsøer, A.K.; Ciliska, D.; Yost, J.; Graverholt, B.; Nortvedt, M.W.; Riise, T.; Espehaug, B. Self-reported and objectively assessed knowledge of evidence-based practice terminology among healthcare students: A cross-sectional study. PLoS ONE 2018, 13, e0200313. [CrossRef]

15. Oh, E.G. Synthesizing quantitative evidence for evidence-based nursing: Systematic review. Asian Nurs. Res. 2016, 10, 89-93. [CrossRef]

16. Glasner-Edwards, S.; Rawson, R. Evidence-based practices in addiction treatment: Review and recommendations for public policy. Health Policy 2010, 97, 93-104. [CrossRef]

17. Nogueira, C., Jr.; Padoveze, M.C. Public policies on healthcare associated infections: A case study of three countries. Health Policy 2018, 122, 991-1000. [CrossRef]

18. Palinkas, L.A.; Saldana, L.; Chou, C.-P.; Chamberlain, P. Use of research evidence and implementation of evidence-based practices in youth-serving systems. Child. Youth Serv. Rev. 2017, 83, 242-247. [CrossRef]

19. Webb, S. Some considerations on the validity of evidence-based practice in social work. Br. J. Soc. Work 2001, 31, 57-79. [CrossRef]

20. Beer, D. Envisioning the power of data analytics. Inf. Commun. Soc. 2018, 21, 465-479. [CrossRef]

21. Poon, S.W.; Tang, S.L.; Wong, F.K.W. Management and Economics of Construction Safety in Hong Kong; Hong Kong University Press: Hong Kong, China, 2008.

22. Lieftink, B.; Smits, A.; Lauche, K. Dual dynamics: Project-based institutional work and subfield differences in the dutch construction industry. Int. J. Proj. Manag. 2019, 37, 269-282. [CrossRef]

23. Li, R.Y.M.; Poon, S.W. Construction Safety; Springer: Berlin/Heidelberg, Germany, 2013.

24. Kaya, T.; Kahraman, C. Multicriteria renewable energy planning using an integrated fuzzy vikor \& ahp methodology: The case of istanbul. Energy 2010, 35, 2517-2527.

25. Fageha, M.K.; Aibinu, A.A. Identifying stakeholders' involvement that enhances project scope definition completeness in saudi arabian public building projects. Built Environ. Proj. Asset Manag. 2016, 6, 6-29. [CrossRef] 
26. Abu Taha, R.; Daim, T. Multi-criteria applications in renewable energy analysis, a literature review. In Research and Technology Management in The electricity Industry: Methods, Tools and Case Studies; Daim, T., Oliver, T., Kim, J., Eds.; Springer: London, UK, 2013; pp. 17-30.

27. Watróbski, J.; Ziemba, P.; Jankowski, J.; Zioło, M. Green energy for a green city-A multi-perspective model approach. Sustainability 2016, 8, 702. [CrossRef]

28. Maruthur, N.M.; Joy, S.M.; Dolan, J.G.; Shihab, H.M.; Singh, S. Use of the analytic hierarchy process for medication decision-making in type 2 diabetes. PLoS ONE 2015, 10, e0126625. [CrossRef] [PubMed]

29. Saaty, T.L. Decision making with the analytic hierarchy process. Int. J. Serv. Sci. 2008, 1, 83-98. [CrossRef]

30. Bian, T.; Hu, J.; Deng, Y. Identifying influential nodes in complex networks based on ahp. Phys. A Stat. Mech. Its Appl. 2017, 479, 422-436. [CrossRef]

31. Ghimire, L.P.; Kim, Y. An analysis on barriers to renewable energy development in the context of nepal using ahp. Renew. Energy 2018, 129, 446-456. [CrossRef]

32. Merchant, J.A.; Lind, D.P.; Kelly, K.M.; Hall, J.L. An employee total health management-based survey of iowa employers. J. Occup. Environ. Med./Am. Coll. Occup. Environ. Med. 2013, 55, S73-S77. [CrossRef]

33. Zhang, G.; Yue, X.G.; Li, F.; Zhao, S.L. Partially stabilised zirconia stability prediction based on opposite degree algorithm for safety engineering. Mater. Res. Innov. 2015, 19. [CrossRef]

34. Yue, X.G.; Zhao, S.L.; Ren, G.F. A new algorithm of sensitivity analysis based on neural network for safety engineering. J. Comput. Theor. Nanosci. 2015, 12, 4111-4113. [CrossRef]

35. Azhar, S.; Choudhry, R.M. Capacity building in construction health and safety research, education, and practice in pakistan. Built Environ. Proj. Asset Manag. 2016, 6, 92-105. [CrossRef]

36. Evanoff, B.; Rohlman, D.; Strickland, J.; Kelly, K.; Dale, A. 519 influence of work organisation and environment on health behaviours of construction apprentices. Occup. Environ. Med. 2018, 75, A588-A589.

37. Chi, C.F.; Chang, T.C.; Ting, H.I. Accident patterns and prevention measures for fatal occupational falls in the construction industry. Appl. Ergon. 2005, 36, 391-400. [CrossRef]

38. Socias-Morales, C.M.; Chaumont Menéndez, C.K.; Marsh, S.M. Fatal work-related falls in the united states, 2003-2014. Am. J. Ind. Med. 2018, 61, 204-215. [CrossRef]

39. Kaskutas, V.; Dale, A.M.; Lipscomb, H.; Evanoff, B. Fall prevention and safety communication training for foremen: Report of a pilot project designed to improve residential construction safety. J. Saf. Res. 2013, 44, 111-118. [CrossRef]

40. Chinniah, Y. Analysis and prevention of serious and fatal accidents related to moving parts of machinery. Saf. Sci. 2015, 75, 163-173. [CrossRef]

41. Aneziris, O.N.; Papazoglou, I.A.; Mud, M.; Damen, M.; Bellamy, L.J.; Manuel, H.J.; Oh, J. Occupational risk quantification owing to falling objects. Saf. Sci. 2014, 69, 57-70. [CrossRef]

42. Fass, S.; Yousef, R.; Liginlal, D.; Vyas, P. Understanding causes of fall and struck-by incidents: What differentiates construction safety in the arabian gulf region? Appl. Ergon. 2017, 58, 515-526. [CrossRef]

43. Dumrak, J.; Mostafa, S.; Kamardeen, I.; Rameezdeen, R. Factors associated with the severity of construction accidents: The case of south australia. Constr. Econ. Build. 2013, 14, 32-49. [CrossRef]

44. Rameezdeen, R.; Elmualim, A. The impact of heat waves on occurrence and severity of construction accidents. Int. J. Environ. Res. Public Health 2017, 14, 70. [CrossRef]

45. Chiang, Y.H.; Wong Francis, K.-W.; Liang, S. Fatal construction accidents in Hong Kong. J. Constr. Eng. Manag. 2018, 144, 04017121. [CrossRef]

46. Li, R.Y.M.; Ng, P.L. Wearable robotics and construction workers safety and health. In Proceedings of the 8th International Conference on Applied Human Factors and Ergonomics, Los Angeles, CA, USA, 17-21 July 2017.

47. Chan, M. Fatigue: The most critical accident risk in oil and gas construction. Constr. Manag. Econ. 2011, 29, 341-353. [CrossRef]

48. Garrett, J.W.; Teizer, J. Human factors analysis classification system relating to human error awareness taxonomy in construction safety. J. Constr. Eng. Manag. 2009, 135, 754-763. [CrossRef]

49. Zhi, M.; Hua, G.B.; Wang, S.Q.; Ofori, G. Total factor productivity growth accounting in the construction industry of singapore. Constr. Manag. Econ. 2003, 21, 707-718. [CrossRef]

50. Li, J.; Yu, M.; Wang, H. A taxonomy of performance shaping factors for shield tunnel construction. Eng. Constr. Arch. Manag. 2018, 25, 574-596. [CrossRef] 
51. Chan, A.H.S.; Kwok, W.Y.; Duffy, V.G. Using ahp for determining priority in a safety management system. Ind. Manag. Data Syst. 2004, 104, 430-445. [CrossRef]

52. Debrah, Y.A.; Ofori, G. Subcontracting, foreign workers and job safety in the singapore construction industry. Asia Pac. Bus. Rev. 2001, 8, 145-166. [CrossRef]

53. Liu, J.; Li, B.; Lin, B.; Nguyen, V. Key issues and challenges of risk management and insurance in china's construction industry: An empirical study. Ind. Manag. Data Syst. 2007, 107, 382-396. [CrossRef]

54. Zahoor, H.; Chan, A.P.C.; Gao, R.; Utama, W.P. The factors contributing to construction accidents in pakistan: Their prioritization using the delphi technique. Eng. Constr. Arch. Manag. 2017, 24, 1-39. [CrossRef]

55. Harvey, E.J.; Waterson, P.; Dainty, A.R.J. Beyond conca: Rethinking causality and construction accidents. Appl. Ergon. 2018, 73, 108-121. [CrossRef]

56. Haslam, R.A.; Hide, S.A.; Gibb, G.F.; Gyi, D.E.; Atkinson, S.; Duff, A.R. Contributing factors in construction accidents. Appl. Ergon. 2005, 36, 401-415. [CrossRef]

57. Mitropoulos, P.; Abdelhamid, T.S.; Howell, G.A. Systems model of construction accident causation. J. Constr. Eng. Manag. 2005, 131, 816-825. [CrossRef]

58. Le, Q.T.; Lee, D.Y.; Park, C.S. A social network system for sharing construction safety and health knowledge. Autom. Constr. 2014, 46, 30-37. [CrossRef]

59. Li, R.Y.M. Construction Safety and Waste Management: An Economic Analysis; Springer: Cham, Switzeralnd, 2015.

60. Lingard, H.; Blismas, N.; Harley, J.; Stranieri, A.; Zhang, R.P.; Pirzadeh, P. Making the invisible visible: Stimulating work health and safety-relevant thinking through the use of infographics in construction design. Eng. Constr. Arch. Manag. 2018, 25, 39-61. [CrossRef]

61. Hassan, H.A.; Houdmont, J. Health and safety implications of recruitment payments in migrant construction workers. Occup. Med. 2014, 64, 331-336.

62. Toole, T.M. Construction site safety roles. J. Constr. Eng. Manag. 2002, 128, 203-210. [CrossRef]

63. Teo, E.A.L.; Ling, F.Y.Y.; Chong, A.F.W. Framework for project managers to manage construction safety. Int. J. Proj. Manag. 2005, 23, 329-341. [CrossRef]

64. Yu, Q.Z.; Ding, L.Y.; Zhou, C.; Luo, H.B. Analysis of factors influencing safety management for metro construction in china. Accid. Anal. Prev. 2014, 68, 131-138. [CrossRef]

65. Irumba, R. Spatial analysis of construction accidents in kampala, uganda. Saf. Sci. 2014, 64, 109-120.

66. Winge, S.; Albrechtsen, E.; Mostue, B.A. Causal factors and connections in construction accidents. Saf. Sci. 2019, 112, 130-141. [CrossRef]

67. Arquillos, A.L.; Romero, J.C.R.; Gibb, A. Analysis of construction accidents in spain, 2003-2008. J. Saf. Res. 2012, 43, 381-388. [CrossRef]

68. Akhmad, S.; Duff, A.R.; Stephen, J.P. Development of causal model of construction accident causation. J. Constr. Eng. Manag. 2001, 127, 337-344.

69. Gambatese, J.; Hinze, J. Addressing construction worker safety in the design phase: Designing for construction worker safety. Autom. Constr. 1999, 8, 643-649. [CrossRef]

70. Behm, M. Linking construction fatalities to the design for construction safety concept. Saf. Sci. 2005, 43, 589-611. [CrossRef]

71. Gambatese, J.A.; Behm, M.; Rajendran, S. Design's role in construction accident causality and prevention: Perspectives from an expert panel. Saf. Sci. 2008, 46, 675-691. [CrossRef]

72. Arocena, P.; Núñez, I. An empirical analysis of the effectiveness of occupational health and safety management systems in smes. Int. Small Bus. J. 2010, 28, 398-419. [CrossRef]

73. Kongtip, P.; Yoosook, W.; Chantanakul, S. Occupational health and safety management in small and medium-sized enterprises: An overview of the situation in thailand. Saf. Sci. 2008, 46, 1356-1368. [CrossRef]

74. Bong, S.; Rameezdeen, R.; Zuo, J.; Li, R.Y.M.; Ye, G. The designer's role in workplace health and safety in construction industry: Post-harmonized regulations in south australia. Int. J. Constr. Manag. 2015, 15, 276-287. [CrossRef]

75. Lingard, H.; Blismas, N.; Wakefield, R.; Cooke, T. Prevention through design: Trade-offs in reducing occupational health and safety risk for the construction and operation of a facility. Built Environ. Proj. Asset Manag. 2013, 3, 7-23. [CrossRef]

76. Malekitabar, H.; Ardeshir, A.; Sebt, M.H.; Stouffs, R. Construction safety risk drivers: A bim approach. Saf. Sci. 2016, 82, 445-455. [CrossRef] 
77. Decker, C.S.; Flynn, D.T. Work-related accidents and the level of market competition: An an analysis of worker injury rates at us steel corportation, 1907-1939. Econ. Inq. 2008, 46, 438-453. [CrossRef]

78. Zhou, Z.; Li, C.; Mi, C.; Qian, L. Exploring the potential use of near-miss information to improve construction safety performance. Sustainability 2019, 11, 1264. [CrossRef]

79. Hu, K.; Rahmandad, H.; Smith-Jackson, T.; Winchester, W. Factors influencing the risk of falls in the construction industry: A review of the evidence. Constr. Manag. Econ. 2011, 29, 397-416. [CrossRef]

80. Ahmad, S.; Iraj, M.; Abbas, M.; Mahdi, A. Analysis of occupational accidents induced human injuries: A case study in construction industries and sites. J. Civ. Eng. Constr. Technol. 2016, 7, 1-7.

81. Eliufoo, H.K. Gendered division of labour in construction sites in zanzibar. Women Manag. Rev. 2007, 22, 112-121. [CrossRef]

82. Cheng, C.W.; Wu, T.C. An investigation and analysis of major accidents involving foreign workers in taiwan's manufacture and construction industries. Saf. Sci. 2013, 57, 223-235. [CrossRef]

83. Gibb, A.; Lingard, H.; Behm, M.; Cooke, T. Construction accident causality: Learning from different countries and differing consequences. Constr. Manag. Econ. 2014, 32, 446-459. [CrossRef]

84. Chong, H.Y.; Low, T.S. Accidents in malaysian construction industry: Statistical data and court cases. Int. J. Occup. Saf. Ergon. 2014, 20, 503-513. [CrossRef]

85. Jabbari, M.; Ghorbani, R. Developing techniques for cause-responsibility analysis of occupational accidents. Accid. Anal. Prev. 2016, 96, 101-107. [CrossRef]

86. Khosravi, Y.; Asilian-Mahabadi, H.; Hajizadeh, E.; Hassanzadeh-Rangi, N.; Bastani, H.; Behzadan, A.H. Factors influencing unsafe behaviors and accidents on construction sites: A review. Int. J. Occup. Saf. Ergon. 2014, 20, 111-125. [CrossRef]

87. Marín, L.S.; Lipscomb, H.; Cifuentes, M.; Punnett, L. Associations between safety climate and safety management practices in the construction industry. Am. J. Ind. Med. 2017, 60, 557-568. [CrossRef]

88. Newaz, M.T.; Davis, P.; Jefferies, M.; Pillay, M. The psychological contract: A missing link between safety climate and safety behaviour on construction sites. Saf. Sci. 2019, 112, 9-17. [CrossRef]

89. Newaz, M.T.; Davis, P.R.; Jefferies, M.; Pillay, M. Developing a safety climate factor model in construction research and practice: A systematic review identifying future directions for research. Eng. Constr. Arch. Manag. 2018, 25, 738-757. [CrossRef]

90. Pandit, B.; Albert, A.; Patil, Y.; Al-Bayati, A.J. Impact of safety climate on hazard recognition and safety risk perception. Saf. Sci. 2019, 113, 44-53. [CrossRef]

91. Probst, T.M.; Goldenhar, L.M.; Byrd, J.L.; Betit, E. The safety climate assessment tool (s-cat): A rubric-based approach to measuring construction safety climate. J. Saf. Res. 2019, 69, 43-51. [CrossRef]

92. Lin, J.; Mills, A. Measuring the occupational health and safety performance of construction companies in australia. Facilities 2001, 19, 131-139. [CrossRef]

93. Dong, X.S.; Fujimoto, A.; Ringen, K.; Men, Y. Fatal falls among hispanic construction workers. Accid. Anal. Prev. 2009, 41, 1047-1052. [CrossRef]

94. Awwad, R.; El Souki, O.; Jabbour, M. Construction safety practices and challenges in a middle eastern developing country. Saf. Sci. 2016, 83,1-11. [CrossRef]

95. Chun, C.K.; Li, H.; Skitmore, M. The use of virtual prototyping for hazard identification in the early design stage. Constr. Innov. Inf. Process. Manag. 2012, 12, 29-42. [CrossRef]

96. Navon, R.; Kolton, O. Model for automated monitoring of fall hazards in building construction. J. Constr. Eng. Manag. 2006, 132, 733-740. [CrossRef]

97. Zhang, F.; Fleyeh, H.; Wang, X.; Lu, M. Construction site accident analysis using text mining and natural language processing techniques. Autom. Constr. 2019, 99, 238-248. [CrossRef]

98. Rowlinson, S.; Jia, Y.A. Construction accident causality: An institutional analysis of heat illness incidents on site. Saf. Sci. 2015, 78, 179-189. [CrossRef]

99. Ning, X.; Qi, J.; Wu, C. A quantitative safety risk assessment model for construction site layout planning. Saf. Sci. 2018, 104, 246-259. [CrossRef]

100. Cakan, H.; Kazan, E.; Usmen, M. Investigation of factors contributing to fatal and nonfatal roofer fall accidents. Int. J. Constr. Educ. Res. 2014, 10, 300-317. [CrossRef]

101. Choi, T.N.Y.; Chan, D.W.M.; Chan, A.P.C. Perceived benefits of applying pay for safety scheme (pfss) in construction-A factor analysis approach. Saf. Sci. 2011, 49, 813-823. [CrossRef] 
102. Chockalingam, S.; Sornakumar, T. Tools for improving safety performance of indian construction industry-AWH \& SIT approach. Eur. J. Econ. Financ. Adm. Sci. 2011, 35, 15-22.

103. Shin, M.; Lee, H.S.; Park, M.; Moon, M.; Han, S. A system dynamics approach for modeling construction workers'safety attitudes and behaviors. Accid. Anal. Prev. 2014, 68, 95-105. [CrossRef]

104. Shin, W.; Jeong, S.C.; Lee, R.N. A study on the causal analysis of death accidents by the falls in the construction sites. J. Korea Saf. Manag. Sci. 2014, 16, 63-69.

105. Xinyu, H.; Jimmie, H. Analysis of construction worker fall accidents. J. Constr. Eng. Manag. 2003, 129, 262-271.

106. Forteza, F.J.; Carretero-Gómez, J.M.; Sesé, A. Occupational risks, accidents on sites and economic performance of construction firms. Saf. Sci. 2017, 94, 61-76. [CrossRef]

107. Winge, S.; Albrechtsen, E. Accident types and barrier failures in the construction industry. Saf. Sci. 2018, 105, 158-166. [CrossRef]

108. Ale, B.J.M.; Bellamy, L.J.; Baksteen, H.; Damen, M.; Goossens, L.H.J.; Hale, A.R.; Mud, M.; Oh, J.; Papazoglou, I.A.; Whiston, J.Y. Accidents in the construction industry in the netherlands: An analysis of accident reports using storybuilder. Reliab. Eng. Syst. Saf. 2008, 93, 1523-1533. [CrossRef]

109. Suárez-Cebador, M.; Rubio-Romero, J.C.; López-Arquillos, A. Severity of electrical accidents in the construction industry in spain. J. Saf. Res. 2014, 48, 63-70. [CrossRef]

110. Baniassadi, F.; Alvanchi, A.; Mostafavi, A. A simulation-based framework for concurrent safety and productivity improvement in construction projects. Eng. Constr. Arch. Manag. 2018, 25, 1501-1515. [CrossRef]

111. Antwi-Afari, M.F.; Li, H. Fall risk assessment of construction workers based on biomechanical gait stability parameters using wearable insole pressure system. Adv. Eng. Inform. 2018, 38, 683-694. [CrossRef]

112. Hinze, J.; Huang, X.; Terry, L. The nature of struck-by accidents. J. Constr. Eng. Manag. 2005, 131, $262-268$. [CrossRef]

113. Liao, C.-W.; Chiang, T.-L. Reducing occupational injuries attributed to inattentional blindness in the construction industry. Saf. Sci. 2016, 89, 129-137. [CrossRef]

114. Nath, N.D.; Chaspari, T.; Behzadan, A.H. Automated ergonomic risk monitoring using body-mounted sensors and machine learning. Adv. Eng. Inform. 2018, 38, 514-526. [CrossRef]

115. Arditi, D.; Ayrancioglu, M.; Shi, J.J. Worker safety issues in night-time highway construction. Eng. Constr. Arch. Manag. 2005, 12, 487-501. [CrossRef]

116. Hintikka, N. Accidents at work during temporary agency work in finland-Comparisons between certain major industries and other industries. Saf. Sci. 2011, 49, 473-483. [CrossRef]

117. Raviv, G.; Fishbain, B.; Shapira, A. Analyzing risk factors in crane-related near-miss and accident reports. Saf. Sci. 2017, 91, 192-205. [CrossRef]

118. Shao, B.; Hu, Z.; Liu, Q.; Chen, S.; He, W. Fatal accident patterns of building construction activities in china. Saf. Sci. 2019, 111, 253-263. [CrossRef]

119. Gurcanli, G.E.; Mungen, U. Analysis of construction accidents in turkey and responsible parties. Ind. Health 2013, 51, 581-595. [CrossRef]

120. Li, R.Y.M. An Economic Analysis on Automated Construction Safety: Internet of Things, Artificial Intelligence and 3D Printing; Springer: Singapore, 2018.

121. Labour Department. Construction Accident. Available online: https://www.labour.gov.hk/eng/news/content. htm (accessed on 1 May 2019).

122. Huestegge, L.; Pötzsch, T.H. Integration processes during frequency graph comprehension: Performance and eye movements while processing tree maps versus pie charts. Appl. Cogn. Psychol. 2018, 32, 200-216. [CrossRef]

123. Shneiderman, B. Tree visualization with tree-maps: 2-D space-filling approach. ACM Trans. Graph. TOG 1992, 11, 92-99. [CrossRef]

(C) 2019 by the authors. Licensee MDPI, Basel, Switzerland. This article is an open access article distributed under the terms and conditions of the Creative Commons Attribution (CC BY) license (http://creativecommons.org/licenses/by/4.0/). 